\title{
Charge Transport and Thermoelectric Properties of Mn-Doped Tetrahedrites $\mathrm{Cu}_{12-\mathrm{x}} \mathrm{Mn}_{\mathrm{x}} \mathrm{Sb}_{4} \mathrm{~S}_{13}$
}

\author{
Sung-Yoon Kim, Go-Eun Lee, and Il-Ho Kim* \\ Department of Materials Science and Engineering, Korea National University of Transportation, Chungju 27469, Republic of Korea
}

\begin{abstract}
Mn-doped tetrahedrites $\mathrm{Cu}_{12-\mathrm{x}} \mathrm{Mn}_{\mathrm{x}} \mathrm{Sb}_{4} \mathrm{~S}_{13}(0.1 \leq \mathrm{x} \leq 0.4)$ were synthesized by mechanical alloying (MA) and sintered by hot pressing (HP). A single tetrahedrite phase was synthesized by MA without post-annealing, and it was stable without any phase changes after HP. The hot-pressed specimens had a relative density higher than $98.6 \%$. The lattice constant of the Mn-doped samples increased compared to that of undoped $\mathrm{Cu}_{12} \mathrm{Sb}_{4} \mathrm{~S}_{13}$, but no significant change in the lattice constant was observed with a change in Mn content. All Mn-doped tetrahedrites acted as p-type semiconductors, as confirmed from positive Hall and Seebeck coefficient values. The Seebeck coefficient increased with increasing temperature but decreased with increasing Mn content; maximum Seebeck coefficient values of $200-219 \mu \mathrm{VK}^{-1}$ were obtained at $323-723 \mathrm{~K}$ for $\mathrm{x}=0.1$. Electrical conductivity increased with increasing temperature and Mn content; the highest electrical conductivity values of $(1.76-2.45) \times 10^{4} \mathrm{Sm}^{-1}$ were obtained at $323-723 \mathrm{~K}$ for $\mathrm{x}=0.4$. As a result, $\mathrm{Cu}_{11.6} \mathrm{Mn}_{0.4} \mathrm{Sb}_{4} \mathrm{~S}_{13}$ exhibited a maximum power factor of $0.80 \mathrm{mWm}^{-1} \mathrm{~K}^{-2}$ at $723 \mathrm{~K}$. As the $\mathrm{Mn}$ content increased, both the electronic and lattice thermal conductivities increased, and thus, the total thermal conductivity was the lowest at $0.48-0.63 \mathrm{Wm}^{-1} \mathrm{~K}^{-1}$ at $323-723 \mathrm{~K}$ for $\mathrm{x}=0.1$. A maximum dimensionless figure of merit of 0.75 was obtained at $723 \mathrm{~K}$ for $\mathrm{Cu}_{11.7} \mathrm{Mn}_{0.3} \mathrm{Sb}_{4} \mathrm{~S}_{13}$. The MA-HP process is suitable for preparing doped tetrahedrites exhibiting excellent thermoelectric performance.
\end{abstract}

(Received February 18, 2021; Accepted March 2, 2021)

Keywords: thermoelectric, tetrahedrite, charge transport, mechanical alloying, hot pressing

\section{Introduction}

Tetrahedrite $\left(\mathrm{Cu}_{12} \mathrm{Sb}_{4} \mathrm{~S}_{13}\right)$ is an earth-abundant sulfosalt mineral composed of low-cost and eco-friendly elements, and lacks toxic elements such as $\mathrm{Pb}$ or $\mathrm{Te}$. In addition, it has the characteristics of a p-type thermoelectric material and exhibits a high dimensionless figure of merit (ZT) at temperatures near $723 \mathrm{~K}$ [1-4]. The tetrahedrite has 58 atoms arranged in a complex crystal structure in a highly symmetrical cubic unit cell (space group $\mathrm{I} \overline{4} 3 \mathrm{~m}$ ) consisting of $\mathrm{CuS}_{4}$ tetrahedra, $\mathrm{CuS}_{3}$ triangles, and $\mathrm{SbS}_{3}$ pyramids [5]. Within the tetrahedrite structure, $\mathrm{Cu}, \mathrm{Sb}$, and $\mathrm{S}$ exist as $\mathrm{Cu}_{10}^{+} \mathrm{Cu}_{2}^{2+} \mathrm{Sb}_{4}^{3+} \mathrm{S}_{13}^{2-}$ [6]. $\mathrm{A} \mathrm{Cu}^{+}$ion located inside a triangular plane of three $\mathrm{S}$ atoms vibrates at high frequency with low energy because of the attractive and repulsive forces of the lone-pair electrons of $\mathrm{Sb}$, thus inducing inherently low lattice thermal conductivity by interfering with heat transfer [7-9]. Studies have been

- 김성윤: 석사과정, 이고은: 박사과정, 김일호: 교수

*Corresponding Author: Il-Ho Kim

[Tel: +82-43-841-5387, E-mail: ihkim@ut.ac.kr]

Copyright (c) The Korean Institute of Metals and Materials conducted to improve the thermoelectric performance of tetrahedrite by partially substituting $\mathrm{Cu}^{+}, \mathrm{Sb}^{3+}$, or $\mathrm{S}^{2-}$ sites with other elements. When $\mathrm{Cu}^{+}$ions are substituted with transition atoms with an oxidation state of $2+$ or $3+$, additional electrons are generated, and the carrier concentration changes, resulting in changes in the charge transport and thermoelectric properties of tetrahedrite.

Pi et al. [10] investigated the thermal stability, mechanical properties, and thermoelectric properties of $\mathrm{Cu}_{11} \mathrm{TrSb}_{4} \mathrm{~S}_{13}(\mathrm{Tr}$ $=\mathrm{Mn} / \mathrm{Fe} / \mathrm{Co} / \mathrm{Ni} / \mathrm{Cu} / \mathrm{Zn}$ ), and reported a $\mathrm{ZT}$ of 0.66 at $723 \mathrm{~K}$ for $\mathrm{Cu}_{12} \mathrm{Sb}_{4} \mathrm{~S}_{13}$. Tippireddy et al. [11] studied the projected density of states, magnetic properties, and thermoelectric properties of $\mathrm{Cu}_{12-\mathrm{x}} \operatorname{Tr}_{\mathrm{x}} \mathrm{Sb}_{4} \mathrm{~S}_{13}(\mathrm{x}=0.5$ for $\mathrm{Tr}=\mathrm{Fe} / \mathrm{Mn}$ and $\mathrm{x}$ $=1$ for $\operatorname{Tr}=\mathrm{Cu} / \mathrm{Co} / \mathrm{Ni} / \mathrm{Zn}$ ) and obtained a $\mathrm{ZT}$ of 0.89 at 700 $\mathrm{K}$ for $\mathrm{Cu}_{11.5} \mathrm{Mn}_{0.5} \mathrm{Sb}_{4} \mathrm{~S}_{13}$. In our previous studies, high $\mathrm{ZT}$ values were achieved for tetrahedrites by doping with transition atoms: $\mathrm{ZT}=0.94$ at $723 \mathrm{~K}$ for $\mathrm{Cu}_{11.8} \mathrm{Co}_{0.2} \mathrm{Sb}_{4} \mathrm{~S}_{13}$ [12], ZT $=0.92$ at $723 \mathrm{~K}$ for $\mathrm{Cu}_{11.8} \mathrm{Ni}_{0.2} \mathrm{Sb}_{4} \mathrm{~S}_{13}$ [13], ZT $=0.80$ at $723 \mathrm{~K}$ for $\mathrm{Cu}_{11.8} \mathrm{Fe}_{0.2} \mathrm{Sb}_{4} \mathrm{~S}_{13}$ [14], and $\mathrm{ZT}=0.76$ at $723 \mathrm{~K}$ for $\mathrm{Cu}_{11.6} \mathrm{Zn}_{0.4} \mathrm{Sb}_{4} \mathrm{~S}_{13}$ [15]. Chetty et al. [16] examined the elastic, magnetic, and thermoelectric properties of $\mathrm{Cu}_{12-}$ 
${ }_{\mathrm{x}} \mathrm{Mn}_{\mathrm{x}} \mathrm{Sb}_{4} \mathrm{~S}_{13}(\mathrm{x}=0-1.8)$. As a result, they achieved a $\mathrm{ZT}$ of 0.76 at $623 \mathrm{~K}$ for $\mathrm{Cu}_{12} \mathrm{Sb}_{4} \mathrm{~S}_{13}$, and among their Mn-doped samples, $\mathrm{Cu}_{11.6} \mathrm{Mn}_{0.4} \mathrm{Sb}_{4} \mathrm{~S}_{13}$ exhibited the highest $\mathrm{ZT}$ of 0.64 at $673 \mathrm{~K}$. Wang et al. [17] studied the thermoelectric properties of $\mathrm{Cu}_{12-\mathrm{x}} \mathrm{Mn}_{\mathrm{x}} \mathrm{Sb}_{4} \mathrm{~S}_{13}(\mathrm{x}=0-2)$ and obtained a ZT of 0.89 at $700 \mathrm{~K}$ for $\mathrm{Cu}_{11.5} \mathrm{Mn}_{0.5} \mathrm{Sb}_{4} \mathrm{~S}_{13}$. Guélou et al. [18] analyzed the atomic displacement parameters to confirm the low-energy vibration of $\mathrm{Cu}$ atoms in $\mathrm{Cu}_{12-\mathrm{x}} \mathrm{Mn}_{\mathrm{x}} \mathrm{Sb}_{4} \mathrm{~S}_{13}(\mathrm{x}=0$ and 1) and achieved a ZT of 0.56 at $573 \mathrm{~K}$ for $\mathrm{Cu}_{11} \mathrm{MnSb}_{4} \mathrm{~S}_{13}$.

Because the boiling temperature of $\mathrm{S}$ is lower than the melting temperature of $\mathrm{Cu}$, the synthesis of tetrahedrite using a typical melting method requires a sophisticated heatingmaintenance-cooling process and long-duration annealing (usually one to two weeks) to achieve phase transformation and homogenization $[19,20]$. However, mechanical alloying (MA) is a low-temperature process, and as a result, volatilization and segregation of component elements do not occur, which is advantageous for the homogenization of the synthetic phase [21]. In our previous study [22], we determined the optimal process conditions for synthesizing $\mathrm{Cu}_{12} \mathrm{Sb}_{4} \mathrm{~S}_{13}$ with MA and hot pressing (HP), and a single tetrahedrite phase was obtained within $24 \mathrm{~h}$ without postannealing. In this study, Mn-doped tetrahedrites were prepared using the MA-HP method, and their charge-transport parameters and thermoelectric properties were examined.

\section{Experimental Procedure}

Mn-doped tetrahedrites $\mathrm{Cu}_{12-\mathrm{x}} \mathrm{Mn}_{\mathrm{x}} \mathrm{Sb}_{4} \mathrm{~S}_{13}(\mathrm{x}=0.1,0.2,0.3$, and 0.4$)$ were synthesized by MA. Elemental powders of $\mathrm{Cu}$ $(<45 \mu \mathrm{m}$, purity $99.9 \%$, Kojundo), Mn $(<45 \mu \mathrm{m}$, purity $99.9 \%$, LTS), Sb (<150 $\mu \mathrm{m}$, purity $99.999 \%$, Kojundo), and $\mathrm{S}$ $(<75 \mu \mathrm{m}$, purity $99.99 \%$, Kojundo) were mixed in a stoichiometric ratio. Next, $20 \mathrm{~g}$ of the mixed powder and $400 \mathrm{~g}$ of $5 \mathrm{~mm}$-diameter stainless steel balls were placed in a hardened steel jar. After the inside of the jar was evacuated, Ar gas was injected and MA was performed for $24 \mathrm{~h}$ at a rotation speed of $350 \mathrm{rpm}$ using a planetary ball mill (Fritsch Pulverisette5). The synthesized powder was loaded onto a graphite mold, and HP was conducted at $723 \mathrm{~K}$ for $2 \mathrm{~h}$ under $70 \mathrm{MPa}$ in vacuum. Details of the MA-HP process have been reported in our previous study [22].

The phases of the hot-pressed specimens were analyzed using X-ray diffraction (XRD; Bruker D8-Advance) with $\mathrm{Cu}$ $\mathrm{K} \alpha$ radiation $\left(\theta-2 \theta\right.$ mode; step size: $0.02^{\circ}$; scan speed: $0.4 \mathrm{~s} /$ step). The lattice constant was calculated using the Rietveld refinement (TOPAS software). Scanning electron microscopy (SEM; FEI Quanta400) and energy-dispersive X-ray spectroscopy (EDS; Bruker Quantax200) were employed to observe the microstructures of the HP specimens. Through elemental mapping, the homogeneous distribution of the elements was confirmed. Charge transport parameters (Hall coefficient, mobility, and carrier concentration) were examined using the van der Pauw method (Keithley 7065) by applying a direct current of $100 \mathrm{~mA}$ and a constant magnetic field of $1 \mathrm{~T}$. The electrical conductivity $(\sigma)$ and Seebeck coefficient $(\alpha)$ were measured simultaneously in the temperature (T) range from 323 to $723 \mathrm{~K}$ using a Ulvac-Riko ZEM-3 system in He atmosphere. Thermal conductivity $(\kappa)$ was determined using the density, specific heat, and thermal diffusivity as measured by the Ulvac-Riko TC-9000H equipment. Finally, the power factor $\left(\mathrm{PF}=\alpha^{2} \sigma\right)$ and dimensionless figure of merit $\left(\mathrm{ZT}=\alpha^{2} \sigma \kappa^{-1} \mathrm{~T}\right)$ were evaluated.

\section{Results and Discussion}

Fig. 1 presents the XRD patterns of Mn-doped tetrahedrite $\mathrm{Cu}_{12-\mathrm{x}} \mathrm{Mn}_{\mathrm{x}} \mathrm{Sb}_{4} \mathrm{~S}_{13}$ specimens synthesized by the MA-HP process. All specimens contained only a single tetrahedrite phase without secondary phases. No significant change was observed in the lattice constant (1.0374-1.0379 nm) with a

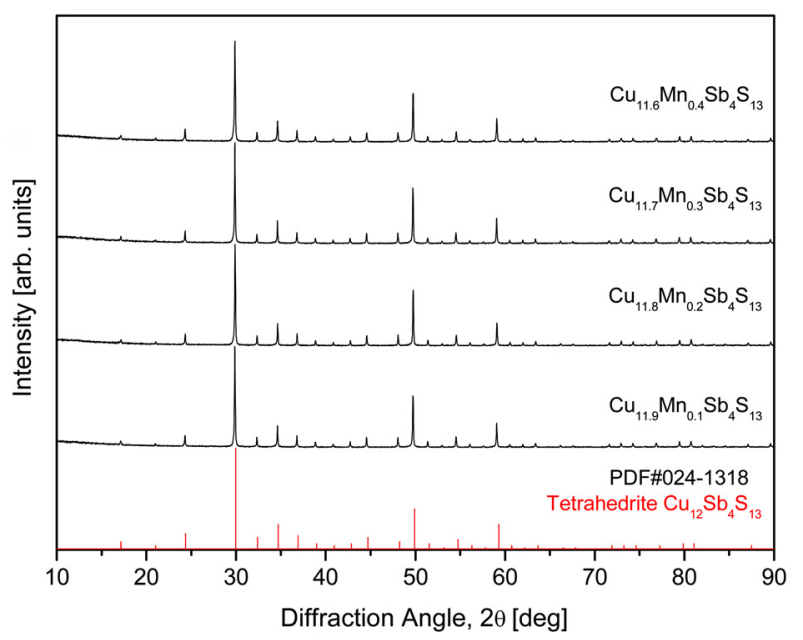

Fig. 1. XRD patterns of $\mathrm{Cu}_{12-\mathrm{x}} \mathrm{Mn}_{\mathrm{x}} \mathrm{Sb}_{4} \mathrm{~S}_{13}$ tetrahedrites prepared by the MA-HP process. 
Table 1. Chemical compositions and physical properties of $\mathrm{Cu}_{12-\mathrm{x}} \mathrm{Mn}_{\mathrm{x}} \mathrm{Sb}_{4} \mathrm{~S}_{13}$.

\begin{tabular}{ccccc}
\hline \multicolumn{2}{c}{ Composition } & $\begin{array}{c}\text { Relative } \\
\text { density [\%] }\end{array}$ & $\begin{array}{c}\text { Lattice } \\
\text { constant [nm }]\end{array}$ & $\begin{array}{c}\text { Lorenz number } \\
{\left[10^{-8} \mathrm{~V}^{2} \mathrm{~K}^{-2}\right]}\end{array}$ \\
\hline Nominal & Actual & 99.8 & 1.0375 & 1.68 \\
$\mathrm{Cu}_{11.9} \mathrm{Mn}_{0.1} \mathrm{Sb}_{4} \mathrm{~S}_{13}$ & $\mathrm{Cu}_{11.80} \mathrm{Mn}_{0.15} \mathrm{Sb}_{4.27} \mathrm{~S}_{12.77}$ & 99.2 & 1.0374 & 1.73 \\
$\mathrm{Cu}_{11.8} \mathrm{Mn}_{0.2} \mathrm{Sb}_{4} \mathrm{~S}_{13}$ & $\mathrm{Cu}_{12.26} \mathrm{Mn}_{0.19} \mathrm{Sb}_{4.15} \mathrm{~S}_{12.40}$ & & 1.0379 & 1.76 \\
$\mathrm{Cu}_{11.7} \mathrm{Mn}_{0.3} \mathrm{Sb}_{4} \mathrm{~S}_{13}$ & $\mathrm{Cu}_{11.36} \mathrm{Mn}_{0.32} \mathrm{Sb}_{4.28} \mathrm{~S}_{13.04}$ & 98.8 & 1.0374 & 1.82 \\
$\mathrm{Cu}_{11.6} \mathrm{Mn}_{0.4} \mathrm{Sb}_{4} \mathrm{~S}_{13}$ & $\mathrm{Cu}_{11.46} \mathrm{Mn}_{0.46} \mathrm{Sb}_{4.13} \mathrm{~S}_{12.95}$ & 98.6 & \\
\hline
\end{tabular}

change in Mn content, as shown in Table 1. However, the lattice constant of doped samples increased compared to that of undoped $\mathrm{Cu}_{12} \mathrm{Sb}_{4} \mathrm{~S}_{13}(1.0350 \mathrm{~nm})$ [10]. This confirmed the successful substitution (doping) of $\mathrm{Mn}$ for the $\mathrm{Cu}$ sites, because the ionic radius of $\mathrm{Mn}^{2+}(66 \mathrm{pm})$ is larger than that of $\mathrm{Cu}^{+}(60 \mathrm{pm})$. Chetty et al. [16] reported an increased lattice constant of $1.043 \mathrm{~nm}$ for $\mathrm{Cu}_{10.2} \mathrm{Mn}_{1.8} \mathrm{Sb}_{4} \mathrm{~S}_{13}$ compared to $1.032 \mathrm{~nm}$ for $\mathrm{Cu}_{12} \mathrm{Sb}_{4} \mathrm{~S}_{13}$. Guélou et al. [18] also obtained similar results of $1.0323 \mathrm{~nm}$ for $\mathrm{Cu}_{12} \mathrm{Sb}_{4} \mathrm{~S}_{13}$ and $1.0386 \mathrm{~nm}$ for $\mathrm{Cu}_{11} \mathrm{MnSb}_{4} \mathrm{~S}_{13}$, showing a significantly increased lattice constant due to Mn substitution. In this study, the amount of Mn substitution ( $\mathrm{x}=0.1-0.4)$ was less than that used in other studies, and thus, the increase in lattice constant was not large.

Fig. 2 displays SEM images of hot-pressed $\mathrm{Cu}_{12-\mathrm{x}} \mathrm{Mn}_{\mathrm{x}}$ $\mathrm{Sb}_{4} \mathrm{~S}_{13}$. No significant difference in microstructure with a change in Mn content was observed, indicating a densely sintered microstructure with few pores. As shown in Table 1, all specimens exhibited high relative densities of $98.6 \%$ $99.8 \%$, and there was no remarkable difference between the nominal and actual compositions. In particular, the composition change resulting from the volatilization of $\mathrm{S}$, which is easily generated in the melting process, was suppressed. The EDS elemental maps showed that each element of $\mathrm{Cu}_{11.7} \mathrm{Mn}_{0.3}$ $\mathrm{Sb}_{4} \mathrm{~S}_{13}$ was homogeneously distributed. In this study, the volatilization of the component elements was suppressed, and compact sintering was successfully achieved using the solidstate MA-HP process.

Fig. 3 shows the carrier concentration and mobility of $\mathrm{Cu}_{12-\mathrm{x}} \mathrm{Mn}_{\mathrm{x}} \mathrm{Sb}_{4} \mathrm{~S}_{13}$. The change in the carrier (hole) concentration according to the Mn content was not large. However, the mobility increased with increasing $\mathrm{Mn}$ content. When $\mathrm{Cu}$ was substituted by $\mathrm{Mn}$, the additionally generated electrons did not meet the expectation that the carrier concentration would decrease due to a reduction in hole concentration (charge compensation). All specimens exhibited positive Hall coefficients, indicating p-type conduction. However, the Hall coefficient values measured in this study were unreliable because a different value was obtained for each measurement. Many studies have failed to effectively measure the Hall coefficient of tetrahedrite $[3,11]$.

The thermoelectric properties of $\mathrm{Cu}_{12-\mathrm{x}} \mathrm{Mn}_{\mathrm{x}} \mathrm{Sb}_{4} \mathrm{~S}_{13}$ were
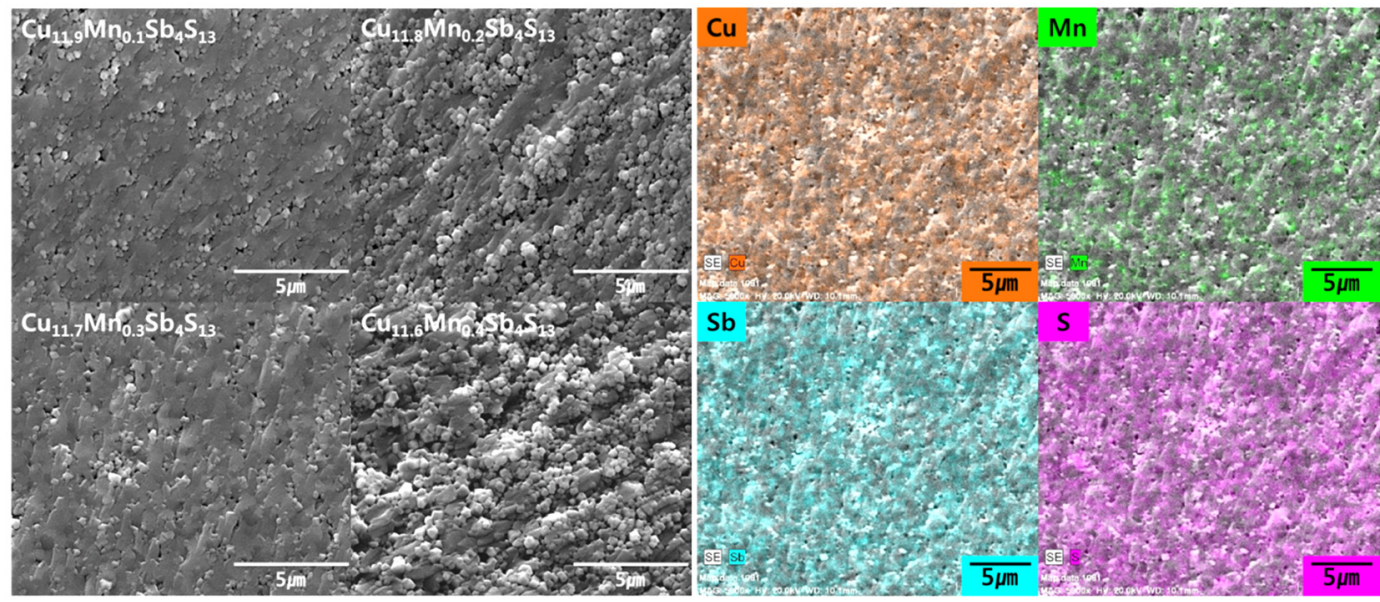

Fig. 2. SEM images of hot-pressed $\mathrm{Cu}_{12-\mathrm{x}} \mathrm{Mn}_{\mathrm{x}} \mathrm{Sb}_{4} \mathrm{~S}_{13}$ and EDS elemental maps of $\mathrm{Cu}_{11.7} \mathrm{Mn}_{0.3} \mathrm{Sb}_{4} \mathrm{~S}_{13}$. 


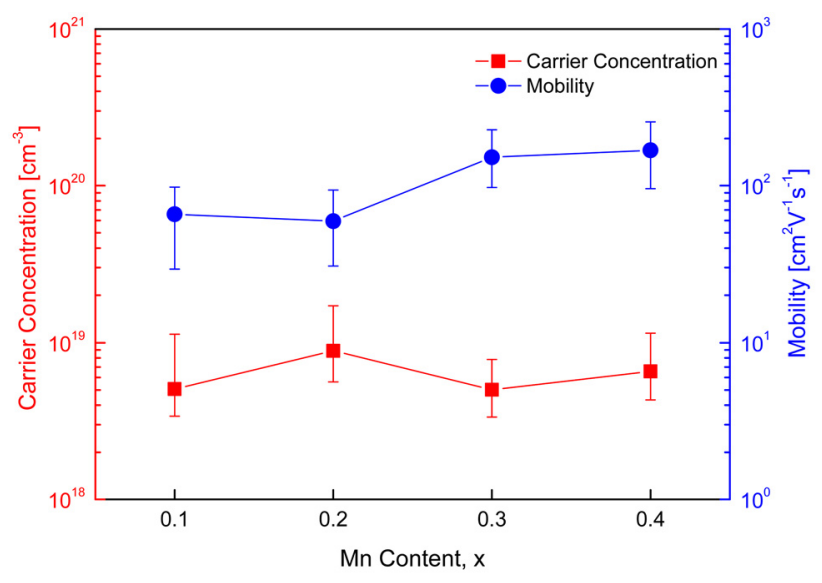

Fig. 3. Charge transport properties of $\mathrm{Cu}_{12-\mathrm{x}} \mathrm{Mn}_{\mathrm{x}} \mathrm{Sb}_{4} \mathrm{~S}_{13}$.

measured and examined in the temperature range of 323-723 K. Fig. 4 presents the Seebeck coefficient of $\mathrm{Cu}_{12-\mathrm{x}} \mathrm{Mn}_{\mathrm{x}}$ $\mathrm{Sb}_{4} \mathrm{~S}_{13}$. Positive Seebeck coefficient values were found for all specimens, suggesting that the major carriers were holes of $\mathrm{p}$ type semiconductors. The Seebeck coefficient is expressed as the relation: $\alpha=(8 / 3) \pi^{2} \mathrm{k}_{\mathrm{B}}^{2} \mathrm{~m}^{*} \mathrm{Te}^{-1} \mathrm{~h}^{-2}(\pi / 3 n)^{2 / 3}$, where $\mathrm{k}_{\mathrm{B}}$ is the Boltzmann constant, $\mathrm{m}^{*}$ is the effective carrier mass, $\mathrm{e}$ is the electronic charge, $\mathrm{h}$ is the Planck constant, and $\mathrm{n}$ is the carrier concentration [23]. The Seebeck coefficient increases as the temperature increases, but when the temperature exceeds a certain temperature (intrinsic transition temperature), the carrier concentration increases rapidly and thus the Seebeck coefficient decreases. As a result, the Seebeck coefficient of a p-type semiconductor decreases after showing a peak value at a specific temperature. In this study, as the temperature

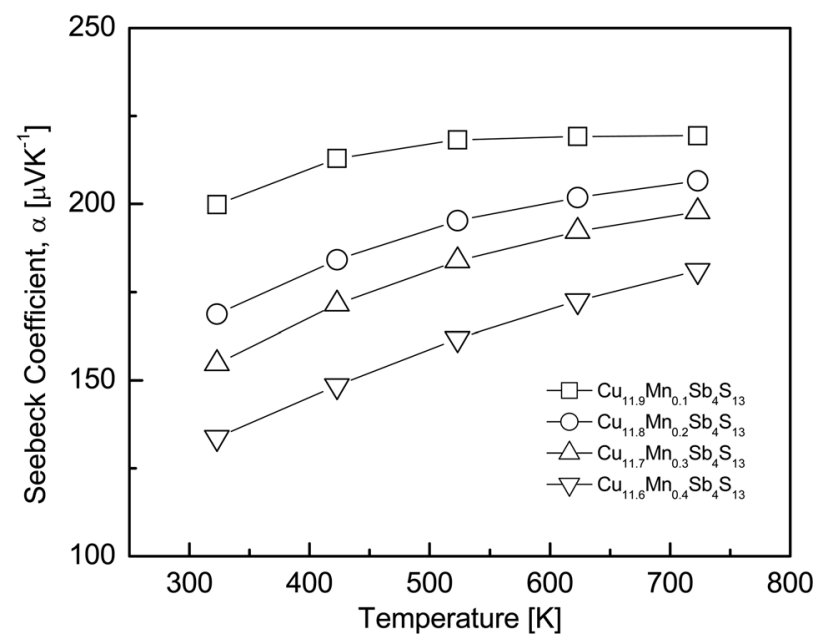

Fig. 4. Seebeck coefficient of $\mathrm{Cu}_{12-\mathrm{x}} \mathrm{Mn}_{\mathrm{x}} \mathrm{Sb}_{4} \mathrm{~S}_{13}$. increased, the Seebeck coefficient increased for all specimens. This implied that no intrinsic transition occurred in the measured temperature range of 323-723 K.

As the Mn content increased at a constant temperature, the Seebeck coefficient decreased and its temperature dependence greatly increased. $\mathrm{Cu}_{11.9} \mathrm{Mn}_{0.1} \mathrm{Sb}_{4} \mathrm{~S}_{13}$ exhibited the highest Seebeck coefficient value of $200-219 \mu \mathrm{VK}^{-1}$ at $323-723 \mathrm{~K}$. This was higher than the $155-195 \mu \mathrm{VK}^{-1}$ at $323-723 \mathrm{~K}$ for undoped $\mathrm{Cu}_{12} \mathrm{Sb}_{4} \mathrm{~S}_{13}$ obtained by Pi et al. [10]. Therefore, the partial substitution of $\mathrm{Mn}$ at the $\mathrm{Cu}$ sites led to an increase in the Seebeck coefficient of tetrahedrite. However, it decreased to $134-181 \mu \mathrm{VK}^{-1}$ at the same temperature for $\mathrm{Cu}_{11.6} \mathrm{Mn}_{0.4}$ $\mathrm{Sb}_{4} \mathrm{~S}_{13}$. Chetty et al. [16] reported increased Seebeck coefficient values from $90-142 \mu \mathrm{VK}^{-1}$ for $\mathrm{Cu}_{12} \mathrm{Sb}_{4} \mathrm{~S}_{13}$ to $96-$ $150 \mu \mathrm{VK}^{-1}$ for $\mathrm{Cu}_{11.6} \mathrm{Mn}_{0.4} \mathrm{Sb}_{4} \mathrm{~S}_{13}$, and $287-400 \mu \mathrm{VK}^{-1}$ for $\mathrm{Cu}_{10.2} \mathrm{Mn}_{1.8} \mathrm{Sb}_{4} \mathrm{~S}_{13}$ at $300-723 \mathrm{~K}$ with increasing $\mathrm{Mn}$ substitution. Wang et al. [17] obtained approximately three-times higher values of $250-325 \mu \mathrm{VK}^{-1}$ for $\mathrm{Cu}_{10} \mathrm{Mn}_{2} \mathrm{Sb}_{4} \mathrm{~S}_{13}$ compared to $77-134 \mu \mathrm{VK}^{-1}$ for undoped $\mathrm{Cu}_{12} \mathrm{Sb}_{4} \mathrm{~S}_{13}$ at temperatures from 300 to $700 \mathrm{~K}$, and they interpreted the reason for the increased Seebeck coefficient: the carrier (hole) concentration decreased because the divalent or trivalent transition element was substituted at the $\mathrm{Cu}^{+}$sites. In this study, although the Seebeck coefficient was increased by Mn doping compared to that of the undoped tetrahedrite, the reason why the Seebeck coefficient decreased with increasing Mn content is still questionable.

Fig. 5 shows the temperature dependence of the electrical conductivity of $\mathrm{Cu}_{12-\mathrm{x}} \mathrm{Mn}_{\mathrm{x}} \mathrm{Sb}_{4} \mathrm{~S}_{13}$. The electrical conductivity increased as the temperature increased and decreased slightly at temperatures above $723 \mathrm{~K}$ for only $\mathrm{Cu}_{11.6} \mathrm{Mn}_{0.4} \mathrm{Sb}_{4} \mathrm{~S}_{13}$. This means that the Mn-doped tetrahedrites behave as nondegenerate semiconductors. The electrical conductivity at a constant temperature increased with increasing Mn content. In this study, the highest electrical conductivity values of (1.82.4) $\times 10^{4} \mathrm{Sm}^{-1}$ were obtained for $\mathrm{Cu}_{11.6} \mathrm{Mn}_{0.4} \mathrm{Sb}_{4} \mathrm{~S}_{13}$ in the temperature range of $323-723 \mathrm{~K}$. These values were slightly higher than those for undoped $\mathrm{Cu}_{12} \mathrm{Sb}_{4} \mathrm{~S}_{13},(1.1-1.9) \times 10^{4}$ $\mathrm{Sm}^{-1}$ at $323-723 \mathrm{~K}[10]$. Mn doping resulted in the opposite trend of what was expected, a decrease in electrical conductivity owing to the decreased hole concentration. Chetty et al. [16] obtained electrical resistivities of 1.013 and $1.693 \mathrm{~m} \Omega \mathrm{cm}$ at $300 \mathrm{~K}$ for $\mathrm{Cu}_{12} \mathrm{Sb}_{4} \mathrm{~S}_{13}$ and $\mathrm{Cu}_{11.6} \mathrm{Mn}_{0.4} \mathrm{Sb}_{4} \mathrm{~S}_{13}$, 


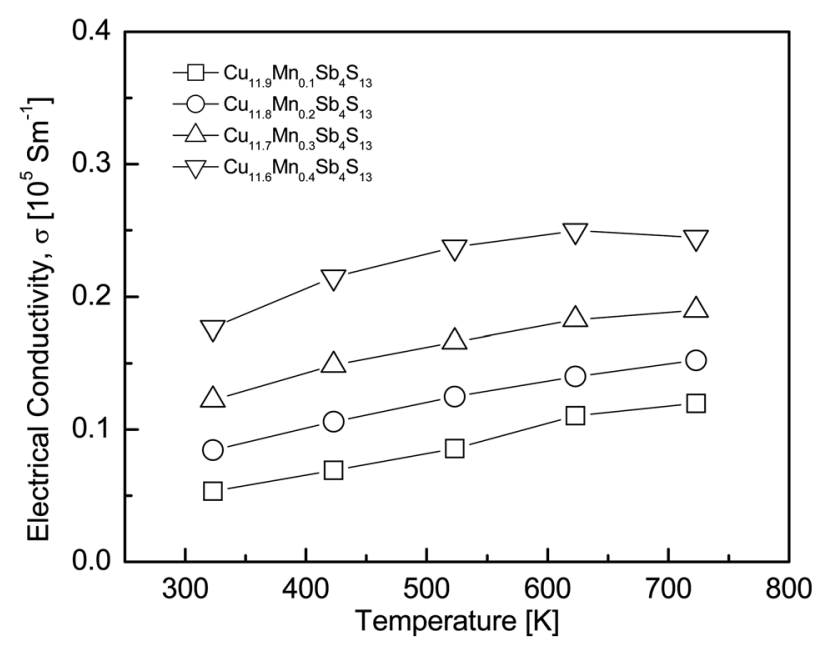

Fig. 5. Electrical conductivity of $\mathrm{Cu}_{12-\mathrm{x}} \mathrm{Mn}_{\mathrm{x}} \mathrm{Sb}_{4} \mathrm{~S}_{13}$.

respectively, with little dependence on temperature, and reported that the electrical resistivity increased (the electrical conductivity increased) to $181-66 \mathrm{~m} \Omega \mathrm{cm}$ at $300-723 \mathrm{~K}$ for $\mathrm{Cu}_{10.2} \mathrm{Mn}_{1.8} \mathrm{Sb}_{4} \mathrm{~S}_{13}$. Wang et al. [17] obtained an electrical conductivity of $(8.6-6.5) \times 10^{4} \mathrm{Sm}^{-1}$ at $300-700 \mathrm{~K}$ for $\mathrm{Cu}_{12} \mathrm{Sb}_{4} \mathrm{~S}_{13}$, a decrease with increasing temperature, and reported an electrical conductivity of $0.1 \times 10^{4} \mathrm{Sm}^{-1}$ at $300 \mathrm{~K}$ for $\mathrm{Cu}_{10} \mathrm{Mn}_{2} \mathrm{Sb}_{4} \mathrm{~S}_{13}$, a decrease with increasing $\mathrm{Mn}$ content with little temperature dependence.

Fig. 6 presents the power factor (PF) of $\mathrm{Cu}_{12-\mathrm{x}} \mathrm{Mn}_{\mathrm{x}} \mathrm{Sb}_{4} \mathrm{~S}_{13}$. Because carrier concentration affects both the Seebeck coefficient and the electrical conductivity, optimization of the carrier concentration is necessary to obtain a high PF value.

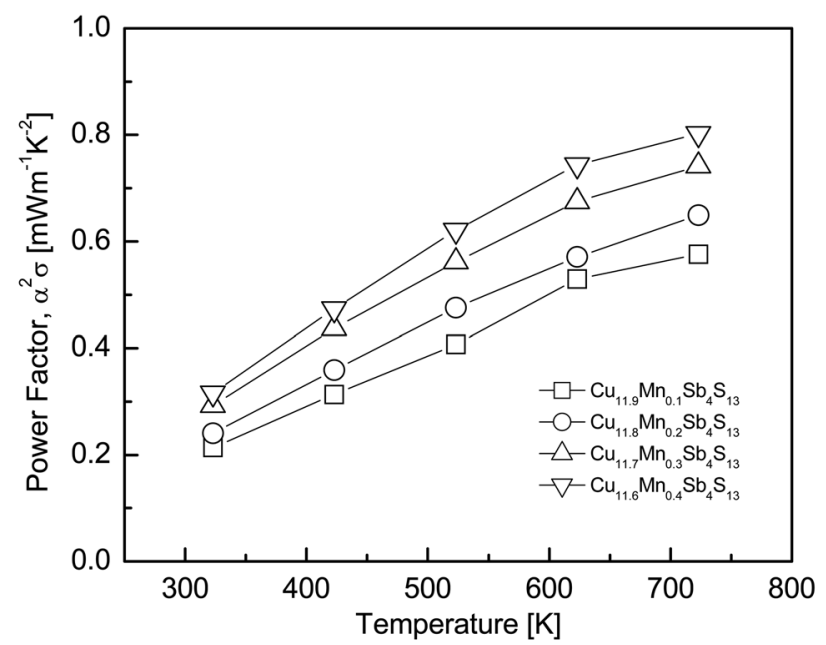

Fig. 6. Power factor of $\mathrm{Cu}_{12-\mathrm{x}} \mathrm{Mn}_{\mathrm{x}} \mathrm{Sb}_{4} \mathrm{~S}_{13}$.
In this study, the PF increased with increasing temperature within the measured temperature range because it did not exceed the intrinsic transition temperature. As the Mn content increased, the PF increased because the increase in electrical conductivity was dominant over the reduction in Seebeck coefficient by $\mathrm{Mn}$ doping. In the case of $\mathrm{Cu}_{11.6} \mathrm{Mn}_{0.4} \mathrm{Sb}_{4} \mathrm{~S}_{13}$, despite having the lowest Seebeck coefficient, the highest PF values of $0.32-0.80 \mathrm{mWm}^{-1} \mathrm{~K}^{-2}$ were obtained in the temperature range of $323-723 \mathrm{~K}$ owing to its highest electrical conductivity. However, Mn doping was not effective at increasing the PF of tetrahedrite; Chetty et al. [16] obtained a maximum $\mathrm{PF}$ of $1.7 \mathrm{mWm}^{-1} \mathrm{~K}^{-2}$ at $623 \mathrm{~K}$ for $\mathrm{Cu}_{12} \mathrm{Sb}_{4} \mathrm{~S}_{13}$, which decreased to $1.2 \mathrm{mWm}^{-1} \mathrm{~K}^{-2}$ at $623 \mathrm{~K}$ for $\mathrm{Cu}_{11.6} \mathrm{Mn}_{0.4}$ $\mathrm{Sb}_{4} \mathrm{~S}_{13}$. Wang et al. [17] reported a maximum $\mathrm{PF}$ of $1.2 \mathrm{mWm}^{-1} \mathrm{~K}^{-2}$ at $700 \mathrm{~K}$ for $\mathrm{Cu}_{12} \mathrm{Sb}_{4} \mathrm{~S}_{13}$, which decreased to
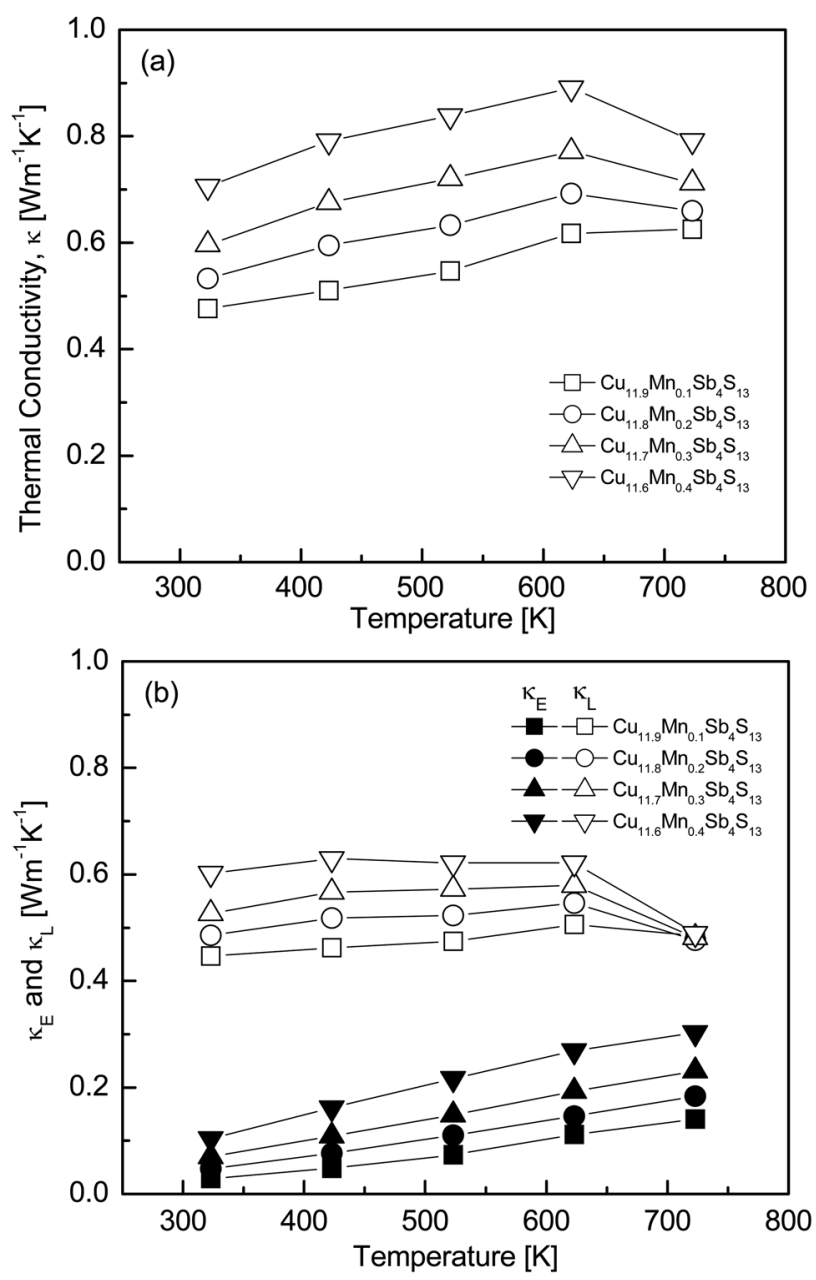

Fig. 7. Thermal conductivity of $\mathrm{Cu}_{12-\mathrm{x}} \mathrm{Mn}_{\mathrm{x}} \mathrm{Sb}_{4} \mathrm{~S}_{13}$ : (a) total thermal conductivity and (b) electronic and lattice thermal conductivities. 
$0.9 \mathrm{mWm}^{-1} \mathrm{~K}^{-2}$ at $675 \mathrm{~K}$ for $\mathrm{Cu}_{11.5} \mathrm{Mn}_{0.5} \mathrm{Sb}_{4} \mathrm{~S}_{13}$.

Fig. 7 shows the temperature dependence of thermal conductivity of $\mathrm{Cu}_{12-\mathrm{x}} \mathrm{Mn}_{\mathrm{x}} \mathrm{Sb}_{4} \mathrm{~S}_{13}$. The maximum total thermal conductivity of all specimens was observed at $623 \mathrm{~K}$, and it increased with increasing $\mathrm{Mn}$ content at a constant temperature. The lattice thermal conductivity $\left(\kappa_{\mathrm{L}}\right)$ was calculated using the equation: $\kappa_{\mathrm{L}}=\kappa-\kappa_{\mathrm{E}}$, where $\kappa$ is the total thermal conductivity and $\kappa_{\mathrm{E}}$ is the electronic thermal conductivity. The $\kappa_{\mathrm{E}}$ was estimated using the WiedemannFranz law ( $\kappa_{\mathrm{E}}=\mathrm{L} \sigma \mathrm{T}$, L: Lorenz number) [24], where the Lorenz number $\left[10^{-8} \mathrm{~V}^{2} \mathrm{~K}^{-2}\right]$ was obtained using the formula [25]. As shown in Table 1, as the Mn content increased, the Lorenz number increased from $1.68 \times 10^{-8}$ to $1.82 \times 10^{-8}$ $\mathrm{V}^{2} \mathrm{~K}^{-2}$ at $323 \mathrm{~K}$. The electronic thermal conductivity increased with increasing temperature, but the total thermal conductivity increased with increasing temperature, reached a maximum at $623 \mathrm{~K}$, and then decreased. This was due to the combined result of increasing electronic thermal conductivity with increasing temperature and decreasing lattice thermal conductivity at temperatures higher than $623 \mathrm{~K}$. The electronic thermal conductivity was directly related to the electrical conductivity (carrier concentration) and Lorenz number, and thus, it increased with increasing Mn content. $\mathrm{Cu}_{11.9} \mathrm{Mn}_{0.1} \mathrm{Sb}_{4} \mathrm{~S}_{13}$ exhibited the lowest lattice thermal conductivity, resulting in the lowest total thermal conductivity of $0.48-0.63 \mathrm{Wm}^{-1} \mathrm{~K}^{-1}$ at $323-723 \mathrm{~K}$, where $\kappa_{\mathrm{E}}$ $=0.03-0.14 \mathrm{Wm}^{-1} \mathrm{~K}^{-1}$ and $\kappa_{\mathrm{L}}=0.45-0.49 \mathrm{Wm}^{-1} \mathrm{~K}^{-1}$.

The dimensionless figure of merit (ZT) of $\mathrm{Cu}_{12-\mathrm{x}} \mathrm{Mn}_{\mathrm{x}} \mathrm{Sb}_{4} \mathrm{~S}_{13}$ is presented in Fig. 8. As the temperature increased, the ZT value increased because of the increase in the PF and the maintenance of low thermal conductivity. In our previous study [10], undoped $\mathrm{Cu}_{12} \mathrm{Sb}_{4} \mathrm{~S}_{13}$ exhibited a ZT of 0.66 at 723 $\mathrm{K}$. In this study, as the Mn content increased, both the thermal conductivity and PF increased. As a result, $\mathrm{Cu}_{11.7} \mathrm{Mn}_{0.3} \mathrm{Sb}_{4} \mathrm{~S}_{13}$ exhibited the highest $\mathrm{ZT}$ of 0.75 at $723 \mathrm{~K}$. Wang et al. [17] reported a ZT of 0.89 at $700 \mathrm{~K}$ for $\mathrm{Cu}_{11.5} \mathrm{Mn}_{0.5} \mathrm{Sb}_{4} \mathrm{~S}_{13}$ prepared by encapsulated melting and HP. Guélou et al. [18] obtained a ZT of 0.56 at $573 \mathrm{~K}$ for $\mathrm{Cu}_{11} \mathrm{MnSb}_{4} \mathrm{~S}_{13}$ produced by MA and HP. Wang et al. [17] performed long-term and careful melting processes; raw elements were heated to $923 \mathrm{~K}$, maintained for $12 \mathrm{~h}$, cooled to room temperature, and then annealed at $723 \mathrm{~K}$ for two weeks. Guélou et al. [18] also conducted long-term and

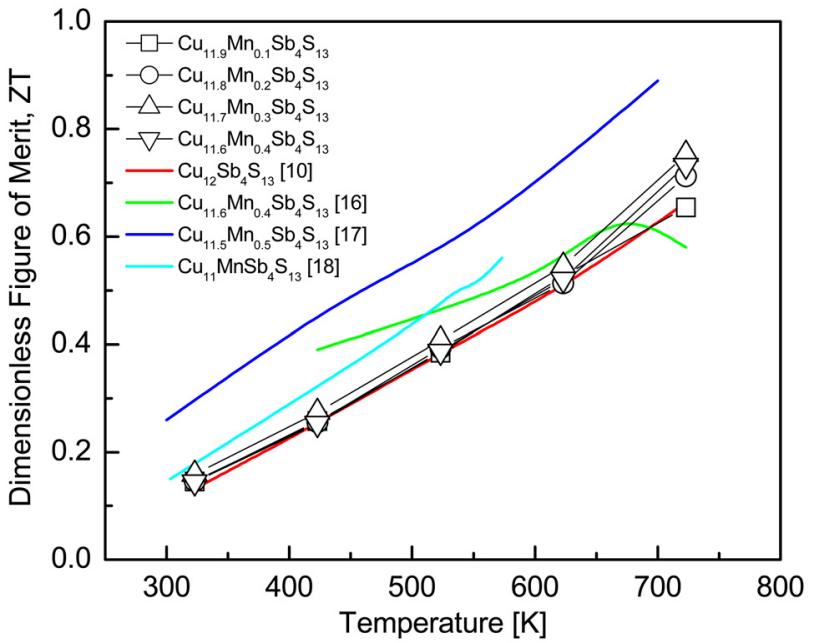

Fig. 8. Dimensionless figure of merit for $\mathrm{Cu}_{12-\mathrm{x}} \mathrm{Mn}_{\mathrm{x}} \mathrm{Sb}_{4} \mathrm{~S}_{13}$.

multi-step processes; samples were mechanically alloyed for $6 \mathrm{~h}$, annealed at $973 \mathrm{~K}$ for $3 \mathrm{~h}$, and cooled to $823 \mathrm{~K}$ for 30 h. The furnace was then cooled to room temperature, and finally, the ingot was crushed and subjected to a second annealing at $823 \mathrm{~K}$ for $30 \mathrm{~h}$. In the present study, however, a single tetrahedrite phase exhibiting a high level of ZT was obtained by MA within $24 \mathrm{~h}$ without post-annealing. Therefore, the MA-HP process is suitable for preparing doped tetrahedrites with excellent thermoelectric performance.

\section{Conclusions}

Mn-doped tetrahedrites $\mathrm{Cu}_{12-\mathrm{x}} \mathrm{Mn}_{\mathrm{x}} \mathrm{Sb}_{4} \mathrm{~S}_{13} \quad(\mathrm{x}=0.1-0.4)$ were synthesized by MA, followed by HP. The hot-pressed specimens had a relative density higher than $98.6 \%$. Positive Hall and Seebeck coefficient values were obtained, meaning that all of the Mn-doped tetrahedrites acted as p-type semiconductors. As the temperature increased, the Seebeck coefficient and electrical conductivity increased. As the Mn content increased, the Seebeck coefficient decreased but the electrical conductivity increased. The trend in electronic thermal conductivity was the same as that of electrical conductivity, and the minimum thermal conductivity was achieved for $\mathrm{Cu}_{11.9} \mathrm{Mn}_{0.1} \mathrm{Sb}_{4} \mathrm{~S}_{13}$. The PF increased because of the increase in electrical conductivity with increasing $\mathrm{Mn}$ doping level. As a result, the maximum $\mathrm{ZT}$ value of 0.75 was obtained at $723 \mathrm{~K}$ for $\mathrm{Cu}_{11.7} \mathrm{Mn}_{0.3} \mathrm{Sb}_{4} \mathrm{~S}_{13}$. 


\section{Acknowledgment}

This study was supported by the Basic Science Research Capacity Enhancement Project (National Research Facilities and Equipment Center) through the Korea Basic Science Institute funded by the Ministry of Education (Grant No. 2019R1A6C1010047).

\section{REFERENCES}

1. X. Lu and D. T. Morelli, Phys. Chem. Chem. Phys. 15, 5762 (2013).

2. K. Suekuni, K. Tsuruta, T. Ariga, and M. Koyano, Appl. Phys. Exp. 5, 1201 (2012).

3. X. Lu, D. T. Morelli, Y. Xia, F. Zhou, V. Ozolins, H. Chi, X. Zhou, and C. Uher, Adv. Energy Mater. 3, 342 (2013).

4. T. Barbier, P. Lemoine, S. Gascoin, O. I. Lebedev, A. Kaltzoglou, P. Vaqueiro, A. V. Powell, R. I. Smith, and E. Guilmeau, J. Alloys Compd. 634, 253 (2015).

5. A. Pfitzner, M. Evain, and V. Petricek, Acta Crystallogr. 53, 337 (1997).

6. R. Chetty, A. Bali, and R. C. Mallik, J. Mater. Chem. C 3, 12364 (2015).

7. B. Lenoir, Y. Bouyrie, C. Candolfi, S. Pailhès, M. M. Koza, B. Malaman, A. Dauscher, J. Tobola, O. Boisron, and L. Saviot, Chem. Phys. 17, 19751 (2015).

8. X. Lu, W. Lai, Y. Wang, and D. T. Morelli, Adv. Funct. Mater. 25, 3648 (2015).

9. D. T. Morelli, E. Lara-Curzio, A. F. May, O. Delaire, M. A. McGuire, X. Lu, C. Y. Liu, and E. D. Case, J. Appl. Phys. 115, 193515 (2014).

10. J. H. Pi, G. E. Lee, and I. H. Kim, J. Electron. Mater. 49, $2710(2020)$.
11. S. Tippireddy, R. Chetty, M. H. Naik, M. Jain, K. Chattopadhyay, and R. C. Mallik, J. Phys. Chem. 122, 8735 (2018).

12. S. Y. Kim, G. E. Lee, and I. H. Kim, J. Korean Phys. Soc. 74, 967 (2019).

13. S. Y. Kim, G. E. Lee, and I. H. Kim, J. Electron. Mater. 49, 2775 (2020).

14. S.-Y. Kim, J.-H. Pi, G.-E. Lee, and I.-H. Kim, Korean J. Met. Mater. 58, 340 (2020).

15. S.-G. Kwak, G.-E. Lee, and I.-H. Kim, Korean J. Met. Mater. 57, 328 (2019).

16. R. Chetty, D. S. P. Kumar, G. Rogl, P. Rogl, E. Bauer, H. Michor, S. Suwas, S. Puchegger, G. Giester, and R. C. Mallik, Phys. Chem. Chem. Phys. 17, 1716 (2015).

17. J. Wang, X. Li, and Y. Bao, Mater. Sci. For. 847, 161 (2016).

18. G. P. L. Guélou, A. V. Powell, R. I. Smith, and P. Vaqueiro, J. Appl. Phys. 126, 045107 (2019).

19. L. L. Huang, J. Zhang, Z. M. Wang, X. G. Zhu, J. M. Li, C. Zhu, D. Li, C. J. Song, H. X. Xin, and X. Y. Qin, Materialia 3, 169 (2018).

20. A. F. May, O. Delaire, J. L. Niedziela, E. Lara-Curzio, M. A. Susner, D. L. Abernathy, M. Kirkham, and M. A. McGuire, Phys. Rev. B 93, 064104 (2016).

21. Y. Q. Yu, B. P. Zhang, Z. H. Ge, P. P. Shang, and Y. X. Chen, Mater. Chem. Phys. 131, 1 (2011).

22. S. Y. Kim, S. G. Kwak, J. H. Pi, G. E. Lee, and I. H. Kim, J. Electron. Mater. 48, 1857 (2019).

23. G. J. Snyder and E. S. Toberer, Nat. Mater. 7, 105 (2008).

24. H. Cailat, A. Borshchevsky, and J. P. Fleurial, J. Appl. Phys. 80, 4442 (1996).

25. B. Madaval and S. J. Hong, J. Electron. Mater. 45, 12 (2016). 